\title{
Orientasi Politik Pemilih Pemula Pada Pilkada Pringsewu 2011 (Studi Pada Siswa/i SMUN di Kabupaten Pringsewu)
}

\author{
Robi Cahyadi Kurniawan \\ Dosen Jurusan Ilmu Pemerintahan, Gedung D Lt 2 FISIP Universitas Lampung \\ Email : robi_ck@yahoo.com
}

\begin{abstract}
Abstrak
Orientasi memilih dipengaruhi oleh beberapa faktor, seperti faktor sosiologis, psikologis dan pilihan rasional. Penelitian ini dilakukan pada bulan Juli sd Agustus 2011 , pada siswa/siswi di empat SMU Negeri (pemilih pemula) yang ada di Pringsewu dengan 200 sampel. Metode yang dipakai adalah kuantitatif deskriftif dengan teknik sampel penarikan sampel bertingkat (stratified purposive sampling). Hasil penelitian Pilkada Pringsewu akan berlangsung dengan tingkat partisipasi yang tinggi, sebesar $92 \%$. Calon Bupati yang diharapkan berasal dari tokoh agama, berusia 41-50 tahun dan beragama Islam. Juga berasal dari putra daerah Pringsewu dan menetap disana. Berjenis kelamin laki-laki. Popularitas calon Bupati, tertinggi dipegang oleh pasangan Ririn K dan pasangan Sujadi.
\end{abstract}

Kata Kunci : Orientasi Memilih, Pemilih Pemula, Pilkada, Pringsewu

\section{Pendahuluan}

Pemilihan presiden dipilih secara langsung, pada tahun 2004, menkalar ke daerah sejak 2005, kepala daerah juga dipilih secara langsung. Pemilihan kepala daerah secara langsung ini diselenggarakan oleh Komisi Pemilihan Umum Daerah (KPUD) dan biayanya ditanggung APBD.

Dua konsekuensi penting dari pemilihan kepala daerah secara langsung. Pertama, suara pemilih akan sangat menentukan. Kemenangan seorang kandidat tergantung kepada seberapa besar kepala daerah dipilih oleh pemilih. Kandidat kepala daerah harus bisa menarik simpati pemilih sebesar mungkin. Pada titik ini, lobi atau politik uang tidak bekerja sama sekali. Kedua, keberhasilan seorang kandidat kepala daerah bisa diukur dari seberapa mampu seorang kandidat menjangkau pemilih.
Kandidat tidak hanya butuh popularitas, kandidat juga membutuhkan penerimaan publik. Pada titik ini, citra kandidat memainkan peranan penting. Apakah kandidat kepala daerah dipersepsikan secara baik atau buruk oleh pemilih. Apakah kandidat kepala daerah dipersepsikan oleh pemilih sebagai sosok yang kompeten atau tidak dalam menyelesaikan masalah yang ada di daerah. Ketiga, preferensi (pilihan). Pada akhirnya popularitas yang tinggi, penerimaan pemilih yang baik, harus bisa diubah menjadi preferensi. Pemilih akan memilih kandidat kepala daerah pada hari pencoblosan.

Jika kandidat kepala daerah ingin memenangkan pemilihan kepala daerah, ia harus menjangkau tiga aspek tersebut. Kandidat harus bisa dikenal oleh sebanyak mungkin pemilih. Setelah dikenal, kandidat harus juga menanamkan citra yang positif di mata pemilih. Dan pada 
akhirnya, mendorong pemilih agar menentukan pilihan pada kandidat kepala daerah. Hanya lewat proses inilah kandidat bisa diterima dan dipilih oleh pemilih. Tidak diperlukan lagi politik uang. Tidak diperlukan lagi lobi atau pengumpulan massa.

Keberhasilan seorang kandidat tidak diukur dari seberapa banyak ia bisa mengumpulkan massa dalam jumlah besar di lapangan saat kampanye. Yang diperlukan oleh kandidat kepala daerah ada terjun dan merebut hati pemilih secara langsung.

Keberhasilan kandidat pada Pemilihan Kepala Daerah secara langsung tergantung kepada berhasil tidaknya kandidat mempengaruhi pemilih. Karena itu kandidat membutuhkan data yang akurat: dari soal popularitas, acceptabilitas hingga preferensi pemilih.

Di level popularitas misalnya. Kandidat membutuhkan data seberapa besar ia dikenal oleh pemilih. Segmen masyarakat mana saja yang belum mengenal, apa strategi yang bisa dilakukan untuk mendekatkan diri dengan pemilih agar lebih dikenal dan sebagainya.

Level acceptabilitas, seorang kandidat juga membutuhkan data yang akurat mengenai bagaimana penilaian publik terhadap personalitas dan kompetensi kandidat. Bagaimana pemilih menilai kandidat: apakah dicitrakan baik atau buruk. Aspek citra positif apa saja yang melekat pada diri kandidat sehiingga bisa dimaksimalkan lewat strategi kampanye. Aspek citra negatif apa yang ada pada diri kandidat sehingga bisa dilakukan langkah antisipasi, dan sebagainya.

Lingkup evel prefersensi, kandidat juga membutuhkan data terpercaya mengenai seberapa besar dukungan pemilih pada kandidat. Bagaimana potensi kandidat dan lawan politik pada hari pencoblosan. Apa strategi yang harus dilakukan untuk meningkatkan dukungan pemilih. Pendek kata, di semua level kandidat membutuhkan data yang terpercaya dan akurat.

Pertanyaannya, alat apa yang bisa dipakai oleh kandidat kepala daerah untuk mendapatkan data tersebut? Kebanyakan politisi melihat besar tidaknya popularitas atau dukungan dari pengumpulan massa saat kampanye. Semakin besar massa yang datang di saat kampanye menandakan ia populer, diterima (acceptabel) dan didukung. Fakta ini seringkali menipu. Banyaknya orang yang berhasil digalang, tidak secara otomatis menandakan besarnaya popularitas dan dukungan pemilih pada seorang kandidat.

Kabupaten Pringsewu sebagai saLah satu dari tiga Daerah Otonomi Baru (DOB) yang akan menggelar hajat Pilkada pada bulan September tahun 2011. Dengan banyaknya calon kandidat kepala daerah dan para wakilnya ditambah dengan calon dari independen, maka perlu kiranya memetakan dukungan pilihan dari masyarakat sekitarnya.

Pemetaan pilihan pendukung ini penting untuk melihat seberapa besar partisipasi politik dari masyarakat khususnya yang ada di Pringsewu. Dapat mengukur angka golput dan selanjutnya dapat memprediksi calon yang akan memenangkan pilkada Bupati Pringsewu mendatang.

Luasnya definisi dari masyaraat, untuk mempermudah dan juga mengkhususkan penelitian ini maka dipilihlah pemilih pemula yang berusia minimal atau diatas 18 tahun 
pada saat pilkada Pringsewu berlangsug yakni September 2011. Latar belakang diatas menjadi alasan bagi peneliti untuk melakukan penelitian tentang; orientasi memilih pemilih pemula pada Pilkada Pringsewu 2011.

\section{Pemilu dan Pilkada}

Salah satu syarat suatu negara yang menganut paham demokrasi adalah adanya sarana untuk menyalurkan aspirasi dan memilih pemimpin negara dengan diadakannya pemilihan umum. Pemilihan umum merupakan sarana untuk mewujudkan kedaulatan rakyat dan menegakan suatu tatanan politik yang demokratis. Artinya pemilu merupakan mekanisme demokratis untuk melakukan pergantian elit politik atau pembuat kebijakan (Laila, 2004:2).

Dari pemilu ini diharapkan lahirnya lembaga perwkilan dan pemerintahan yang demokratis. Salah satu fungsinya adalah sebagai alat penegak atau penyempurna demokrasi dan bukan sebagai tujuan demokrasi.

Menurut Undang-Undang Pemilu No. 22 Tahun 2007 tentang Penyelenggaraan Pemilihan umum bahwa :

"Pemilihan umum merupakan
sarana untuk $r$ mewujudkan
kedaulatan rakyat $r$ dalam
pemerintahan Negara Kesatuan
Republik Indonesia negara yang
berdasarkan Pancasila dsebagaimana
diamanatkan dalam Undang-Undang
Dasar Negara Republik Indinesia
Tahun 1945"
Sedangkan menurut Karim
dalam Dani (2006:11) Pemilihan
umum adalah:

"Sarana demokrasi untuk membentuk sistem kekuasaan negara yang pada dasarnya lahir dari bawah menurut kehendak rakyat sehingga terbentuk kekuasaan negara yang benar-benar memancar kebawah sebagai suatu kewibawaan yang sesuai dengan keinginan rakyat, oleh rakyat.

Dapat disimpulkan bahwa pemilihan umum merupakan sarana legitimasi bagi sebuah kekuasaan. Artinya pemilu merupakan roh demokrasi yang benar-benar merupakan sarana pemberian mandat kedaulatan rakyat.

\section{Perilaku Politik dan Orientasi Memilih}

Surbakti (1992:131), perilaku politik dirumuskan sebagai kegiatan yang berkenaan dengan proses pembuatan dan pelaksanaan keputusan politik, yang melakukan kegiatan adalah pemerintah dan masyarakat. Kegiatan yang dilaksanakan pada dasarnya dibagi menjadi dua, yaitu fungsi-fungsi pemerintahan yang dipegang oleh pemerintah dan fungsi-fungsi politik yang dipegang oleh masyarakat.

Pendapat tersebut juga diperkuat oleh Rahman (1998:123), yang mengatakan bahwa perilaku politik sering dirumuskan sebagai kegiatan yang berkenaan dengan proses pembuatan dan pelaksanaan keputusan politik. Adapun yang melakukan kegiatan politik adalah pemerintah dan masyarakat sesuai dengan fungsinya masing-masing.

Menurut Surbakti (1992:132), dalam melakukan kajian terhadap perilaku politik dapat dipilih tiga kemungkinan unit analisis, yakni individu, aktor politik, agregasi politik dan tipologi kepribadian politik. Adapun dalam kategori 
individu aktor individu aktor politik meliputi aktor politik (pemimpin), aktivitas politik dan individu warga negara biasa. Agregasi politik adalah individu aktor politik secara kolektif, seperti kelompok kepentingan, birokrasi, partai politik, lembagalembaga pemerintahan dan bangsa. Sedangkan yang dipelajari dalam tipologi kepribadian politik adalah tipe-tipe kepribadian pemimpin otoriter, Machiavelist dan demokrat.

Secara garis besar pemaparan diatas dapat disimpulkan bahwa perilaku politik adalah kegiatan yang selalu berkaitan dengan proses pembuatan dan pelaksanaan keputusan politik yang dilakukan oleh pemerintah dan masyarakat dalam menjalankan fungsinya masing-masing, yakni pemerintah menjalankan fungsi pemerintahan dan masyarakat menjalankan fungsifungsi politiknya.

Kristiadi (1996:76) berpendapat bahwa, perilaku pemilih adalah keterikatan seseorang untuk memberikan suara dalam proses pemilihan umum berdasarkan faktor psikologis, faktor sosiologis dan faktor rasional pemilih atau disebut teori voting behavioral. Mahendra (2005:75) mengatakan, perilaku pemilih adalah tindakan seseorang ikut serta dalam memilih orang, partai politik atau isu publik tertentu.

\section{METODE PENELITIAN}

Penelitian ini menggunakan metode penelitian kuantitatif deskriptif. Melalui teknik survey atau jejak pendapat. Survei atau jajak pendapat adalah cara modern untuk mengetahui pendapat masyarakat. Disebut modern karena survei memakai teknik dan metode penelitian ilmiah untuk mengukur pendapat masyarakat. Survey adalah cara untuk mengetahui pendapat masyarakat atau pilihan pemilih, hanya dengan mewawancarai sedikit orang.Metode sampel yang dipakai untuk mendapatkan sampel yang representatif adalah metode penarikan sampel bertingkat (stratified purposive sampling). .

Metode ini dipakai untuk mendapatkan sampel dari karakter populasi yang hampir seragam. Penarikan sampel dilakukan secara bertingkat. Pertama, menarik sampel sekolah SMU di Kabupaten Pringsewu. Peneliti akan mendata semua sekolah SMU yang ada dalam satu daerah ( kabupaten / kota). Dari situ lalu diambil secara purposif (ditentukan) SMU terpilih. Kedua, setelah SMU terpilih, ditentukan siswa kelas 3 SMU saja yang akan ditarik sampel, karena rata-rata kelas 3 sudah berusia 18 tahun keatas atau akan 18 tahun pada tanggal 28 September 2011. Ketiga, setelah siswa kelas 3 SMU ditemukan, lalu sampel dibagi menjadi 2 kelompok, pertama kelompok siswa kelas 3 SMU jurusan IPA dan kedua; kelompok kelas 3 SMU jurusan IPS. Pembagian Sampel sbb :

\begin{tabular}{|c|c|c|c|}
\hline No. & Nama Sekolah (SMUN) & Jumlah Sampel & Kelompok Sampel \\
\hline 1. & SMUN 1 Pagelaran & 50 Sampel & $\begin{array}{c}25 \text { Kelompok IPA } \\
25 \text { siswa/i kel IPS }\end{array}$ \\
\hline 2. & SMUN 1 Ambarawa & 50 Sampel & idem \\
\hline 3. & SMUN 1 Pardasuka & 50 Sampel & idem \\
\hline 4. & SMUN 1 Banyumas & 50 Sampel & idem \\
\hline & TOTAL & 200 sampel & \\
\hline
\end{tabular}




\section{Gambaran Kognitif Pilkada}

Penjelasan tentang gambaran popularitas calon disajikan pada segmen ini, meliputi pengenalan responden terhadap seluruh calon, interaksi reponden dengan para calon, sumber informasi yang responden dapatkan tentang calon serta kandidat yang paling dikenal oleh responden.

Tabel 1.

Pengetahuan tentang Pilkada Pringsewu 2011

\begin{tabular}{|l|c|c|c|}
\hline Pertanyaan & Jawaban & Jumlah (200) & $\%$ \\
\hline Apakah sdr/I mengetahui pada bln & Ya, tahu & 184 & $92 \%$ \\
\cline { 2 - 4 } September 2011 akan ada Pilkada? & Tidak Tahu & 16 & $8 \%$ \\
\hline
\end{tabular}

Sumber : Data diolah, Agustus 2011

Pemilih pemula di Kabupaten Pringsewu sebagian besar mengetahui tentang akan diadakannya kegiatan pemilihan Kepala Daerah yang akan berlangsung pada tanggal 28 September 2011 mendatang. Sebanyak $92 \%$ responden mengetahui akan hal itu.

Tabel 2.

Definisi Populer menurut responden.

\begin{tabular}{|l|l|c|c|}
\hline \multicolumn{1}{|c|}{ Pertanyaan. } & \multicolumn{1}{|c|}{ Jawaban } & $\begin{array}{c}\text { Jumlah } \\
(200)\end{array}$ & $\%$ \\
\hline $\begin{array}{l}\text { Apakah } \\
\text { definisi/pengertian } \\
\text { Populer menurut sdr/i } ?\end{array}$ & a. Terkenal dan dikenal & 148 & $74 \%$ \\
\cline { 2 - 4 } & b. Disukai banyak orang & 31 & $15,5 \%$ \\
\cline { 2 - 4 } & c. Sering di bicarakan & 14 & $7 \%$ \\
\cline { 2 - 4 } & $\begin{array}{l}\text { d. Jawaban lain : } \\
-\begin{array}{l}\text { ada di baliho } \\
- \text { Dimuat dikoran }\end{array}\end{array}$ & 7 & $3,5 \%$ \\
\hline
\end{tabular}

Sumber : Data diolah, Agustus 2011

Populer dalam kacamata responden ternyata tidak terlalu jauh dengan pengertian terkenal dan dikenal oleh banyak khalayak khususnya masyarakat di Kabupaten pringsewu. Sebanyak $74 \%$ responden menjawab definisi itu. Disukai oleh orang banyak dijawab oleh $15,5 \%$ dari total responden,

Isi dari tabel 3 dibawah memperlihatkan bahwa kebanyakan dari responden (62 \%) tidak mengenal para calon kandidat yang akan bertarung pada Pilkada Kabupaten Pringsewu 2011 mendatang. Ketika ditanyakan kembali dengan pertanyaan terbuka, kenapa tidak mengenal calon, jawaban bervariasi dimulai dari tidak pernah tahu keberadaan mereka selama ini di Pringsewu. Jawaban lain, tidak pernah melihat dan berkomunikasi dengan para calon. Sampai dengan jawaban para calon hanya dikenal saat di baliho dan spanduk dipasang.

Responden yang menjawab mengenal para calon (38 \%) dikarenakan faktor hubungan keluarga atau family dengan para 
calon, khususnya para calon yang putra daerah asli dan tinggal atau menetap di Kabupaten Pringsewu. Mengenal para calon juga dijawab oleh responden karena hubungan tetangga, disebabkan rumah tempat tinggal responden dekat atau bersebrangan dengan para calon.

Tabel 3.

Tingkat pengetahuan terhadap calon Bupati dan Wakil Bupati yang akan bertarung dalam Pilkada 2011

\begin{tabular}{|l|c|c|c|}
\hline \multicolumn{1}{|c|}{ Pertanyaan } & Jawaban & Jumlah (200) & $\%$ \\
\hline $\begin{array}{l}\text { Apakah sdr/I tahu atau mengenal para } \\
\text { calon }\end{array}$ & Ya , tahu & 76 & $38 \%$ \\
Bupati dan Wakil Bupati di Pringsewu? & Tidak tahu & 124 & $62 \%$ \\
\cline { 2 - 4 }
\end{tabular}

Sumber : Data diolah, Agustus 2011

Tabel 4.

Bertemu atau berkomunikasi dengan calon Bupati dan Wakil Bupati Pringsewu.

\begin{tabular}{|c|c|c|c|}
\hline Pertanyaan & Jawaban & $\begin{array}{c}\text { Jumlah } \\
\text { (200) }\end{array}$ & $\%$ \\
\hline \multirow{3}{*}{$\begin{array}{l}\text { Apakah anda pernah bertemu } \\
\text { atau berkomunikasi dengan } \\
\text { Para calon Bupati/ Wakil Bupati }\end{array}$} & a.ya, bertemu langsung & 36 & $18 \%$ \\
\hline & b. ya, berkomunikasi & 6 & $3 \%$ \\
\hline & c. tidak pernah & 158 & $79 \%$ \\
\hline
\end{tabular}

Sumber : Data diolah, Agustus 2011

Data pada tabel 4 memberikan gambaran bahwa responden jarang bertemu dan berkomunikasi langsung dengan para calon kandidat Bupati dan Wakil Bupati Pringsewu 20112016. Data ini dapat diasumsikan bahwa para calon Bupati dan Wakil Bupati Pringsewu belum memperhatikan peluang dalam menggalang suara dari pemilih pemula. Hal ini menurut pendapat peneliti bisa disebabkan oleh dua faktor. Pertama; belum dimulainya kampanye efektif antara para calon dengan warga pringsewu khususnya pemilh pemula. Kedua; pemilih pemula bagi para calon bukanlah prioritas utama dalam menggaet suara karena jumlahnya yang dianggap tidak signifikan.Atau presentase jumlah yang tidak banyak.

Tabel 5.

Sumber informasi mengenal para calon Bupati dan wakil Bupati

\begin{tabular}{|l|l|c|c|}
\hline \multicolumn{1}{|c|}{ Pertanyaan } & \multicolumn{1}{|c|}{ Jawaban } & $\begin{array}{c}\text { Jumlah } \\
(200)\end{array}$ & $\%$ \\
\hline \multirow{2}{*}{$\begin{array}{l}\text { Sumber Informasi saudara/i } \\
\text { mengenal para calon Bupati/wakil }\end{array}$} & a.Media Massa & 36 & $18 \%$ \\
\cline { 2 - 4 } & b. Teman atau sahabat & 14 & $7 \%$ \\
\cline { 2 - 4 } & c. Keluarga & 44 & $22 \%$ \\
\cline { 2 - 4 } & $\begin{array}{l}\text { d.Baliho, spanduk, } \\
\text { pamflet }\end{array}$ & 106 & $53 \%$ \\
\hline
\end{tabular}

Sumber : Data diolah, Agustus 2011 
Tabel 5 diatas menunjukan bahwa pemasangan baliho, pamphlet atau spanduk jauh-jauh hari sebelum penetapan pasangan calon terbukti efektif sebagai sarana informasi bagi publik khususnya pemilih pemula di
Kabupaten Pringsewu sebesar $53 \%$. Diurutan kedua ternyata keluarga menempati peringkat selanjutnya $(22$ $\%$ ) sebagai sumber informasi pemilih pemula mengenal para kandidat calon.

Tabel 6.

Kandidat pasangan calon yang dikenal dengan baik.

\begin{tabular}{|l|l|c|c|}
\hline \multicolumn{1}{|c|}{ Pertanyaan } & \multicolumn{1}{|c|}{ Jawaban } & $\begin{array}{c}\text { Jumlah } \\
(200)\end{array}$ & $\%$ \\
\hline Diantara para calon bupati/ & $\begin{array}{l}\text { a.Ririn Kuswantari \& Subhan } \\
\text { Efendi }\end{array}$ & 21 & $11,5 \%$ \\
\cline { 2 - 4 } wakilBupati Pringsewu & $\begin{array}{l}\text { b.Abd. Fadri Auli \& Tri } \\
\text { Prawoto }\end{array}$ & 8 & $4 \%$ \\
\cline { 2 - 4 } kalon manakah yang anda & $\begin{array}{l}\text { c. Untung Subroto \& } \\
\text { Purwantoro }\end{array}$ & 10 & $5 \%$ \\
\cline { 2 - 4 } & $\begin{array}{l}\text { d.Sujadi S. \& Handitya } \\
\text { Narapati }\end{array}$ & 14 & $7 \%$ \\
\cline { 2 - 4 } & $\begin{array}{l}\text { e.Sinung Gatot W \& Mat Alfi } \\
\text { Asha }\end{array}$ & 12 & $6 \%$ \\
\cline { 2 - 4 } & f.Tidak kenal & 133 & $66,5 \%$ \\
\hline
\end{tabular}

Sumber : Data diolah, Agustus 2011

Responden yakni pemilih pemula di Pringsewu banyak yang tidak mengenal kandidat pasangan calon dengan baik sebesar 66,5\%. Definisi dikenal dengan baik yakni pernah bertemu, pernah berkomunikasi dua arah artinya antara responden (pemilih pemula) dengan para kandidat saling mengenal antara keduanya. Atau hanya responden yang mengenal, walaupun responden masih ragu apakah jika bertemu dan berkomunikasi kembali para kandidat masih mengenal mereka.

Data menunjukkan bahwa pasangan Ririn dan Subhan adalah Tabel 7

Penilaian terhadap tingkah laku, kinerja ataupun track record para calon

\begin{tabular}{|l|c|c|c|}
\hline \multicolumn{1}{|c|}{ Pertanyaan } & Jawaban & Jumlah (200) & $\%$ \\
\hline Secara keseluruhan bagaimana & a. Sangat baik & 6 & $3 \%$ \\
\cline { 2 - 4 } $\begin{array}{l}\text { Anda menilai kinerja, tingkah } \\
\text { laku }\end{array}$ & b. Baik & 12 & $6 \%$ \\
$\begin{array}{l}\text { atau rekam jejak para calon } \\
\text { kandidat yang akan bertarung }\end{array}$ & c. Cukup baik & 132 & $66 \%$ \\
\cline { 2 - 4 } & d. Kurang baik & 23 & $11,5 \%$ \\
\hline
\end{tabular}

yang paling dikenal oleh responden. $(11,5 \%)$. Menurut pendapat peneliti, hal ini wajar karena tokoh Ririn adalah penduduk asli Pringsewu yang lahir dan besar di Ambarawa. Sampel dalam penelitian ini salah satunya adalah SMUN 1 Ambarawa yang kebanyakan siswa dan siswinya berdomisili di Ambarawa. Pasangan Sujadi dan Handitya menempati posisi kedua dikenal oleh responden (7 \%), karena Sujadi adalah tokoh Nahdatul Ulama yang terkenal di Kabupaten Pringsewu dan sebelum mencalonkan diri menjabat sebagai Wakil Bupati Kabupaten Tanggamus. 
di Pilkada Pringsewu 2011 ?

\begin{tabular}{|c|c|c|}
\hline e. Tidak baik & 17 & $8,5 \%$ \\
\hline $\begin{array}{ll}\text { f. } & \text { Tidak jawab }\end{array}$ & 10 & $5 \%$ \\
\hline
\end{tabular}

Sumber : Data diolah, Agustus 2011

Hal unik tersaji pada data tabel 7 , walaupun responden banyak yang tidak mengenal para kandidat calon, namun mereka menunjukkan apresiasi yang cukup baik untuk menilai track record calon, yakni sebesar $66 \%$. Jawaban presentase cukup baik ini menurut pendapat peneliti lebih disebabkan kurangnya informasi yang masuk dan dapat diolah oleh responden. Sehingga jawaban cukup baik berasal dari

terkaan atau pendapat sementara para responden.

\section{Orientasi Memilih Pemilih Pemula}

Bagian ini menjelaskan tentang orientasi memilih para responden, dimulai dari penggunaan hak pillih, orientasi asal daerah calon yang akan dipilih, jenis kelamin, latar belakang, usia, agama, penegalaman di birokrasi, parpol pengusung, pasangan yang akan dipilih beserta alasan mengapa dipilih.

Tabel 8.

Memakai hak pilih pada Pilkada 2011

\begin{tabular}{|l|c|c|c|}
\hline \multicolumn{1}{|c|}{ Pertanyaan } & Jawaban & Jumlah (200) & $\%$ \\
\hline $\begin{array}{l}\text { Apakah saudara/i akan } \\
\text { menggunakan }\end{array}$ & Ya & 159 & $79,5 \%$ \\
\cline { 2 - 4 } hak pilih pada Pilkada Pringsewu & Tidak & 14 & $7 \%$ \\
\cline { 2 - 4 } & Tidak tahu & 27 & $13,5 \%$ \\
\hline
\end{tabular}

Sumber: Data diolah , Agustus 2011

Sebagian besar responden akan menggunakan hak pilihnya pada pilkada Pringsewu 28 September mendatang. Sebanyak 159 responden atau 79,5 \% memilih untuk menggunakan hak pilihnya. Sebanyak 14 responden tidak akan menggunakan hak pilihnya, pada sesi pertanyaan terbuka alasan mereka tidak memilih adalah malas atau alasan pergi keluar kota jika hari itu diliburkan. Responden yang menjawab tidak tahu sebesar 13,5\% , tidak tahu dalam pengertian masih melihat situasi pada hari pemilihan, misalnya hujan atau tidak, TPS jauh atau dekat dengan kediaman atau menunggu keputusan keluarga jika hendak bepergian keluar kota.

Tabel 9.

Asal daerah calon yang akan di pilih

\begin{tabular}{|c|l|c|c|}
\hline Pertanyaan & \multicolumn{1}{|c|}{ Jawaban } & Jumlah (200) & $\%$ \\
\hline \multirow{2}{*}{$\begin{array}{c}\text { Asal daerah calon yang } \\
\text { akan sdr/i pilih. }\end{array}$} & a.putra daerah, menetap & 122 & $61 \%$ \\
\cline { 2 - 4 } & $\begin{array}{l}\text { b.putra daerah, tidak } \\
\text { menetap }\end{array}$ & 56 & $28 \%$ \\
\cline { 2 - 4 } & $\begin{array}{l}\text { c. asal daerah tidak } \\
\text { masalah }\end{array}$ & 22 & $11 \%$ \\
\hline
\end{tabular}

Sumber : Data diolah , Agustus 2011

Responden lebih memilih putra daerah yang menetap dan tinggal di
Kabupaten Pringsewu sebagai calon Bupati setempat. Besarnya jumlah 
responden yang memilih (61 \%) menunjukkan bahwa putra daerah yang tinggal dan menetap dapat memperhatikan kondisi daerah dan mempercepat proses pembangunan karena mengenal permasalahan dan tantangan yang ada di daerah Pringsewu.

Tabel 10.

Jenis Kelamin calon

\begin{tabular}{|l|l|c|c|}
\hline \multicolumn{1}{|c|}{ Pertanyaan } & \multicolumn{1}{|c|}{ Jawaban } & Jumlah (200) & $\%$ \\
\hline Apakah jenis kelamin \\
$\begin{array}{l}\text { Calon Bupati/wakil yang } \\
\text { Sdr/i inginkan? }\end{array}$ & Laki-laki & 94 & $48 \%$ \\
\cline { 2 - 4 } & Perempuan & 30 & $15 \%$ \\
\cline { 2 - 4 } & $\begin{array}{l}\text { Apapun tidak } \\
\text { masalah }\end{array}$ & 74 & $37 \%$ \\
\hline
\end{tabular}

Sumber : Data diolah, Agustus 2011

Laki-laki masih menjadi pilihan utama untuk menjadi calon Bupati Pringsewu, sebanyak $48 \%$ responden memilih laki-laki sebagai Bupati. Dominasi laki-laki secara statistik memang besar namun peluang perempuan juga tidak kecil karena total $52 \%$ responden dengan rincian memilih perempuan $15 \%$ dan jenis kelamin tidak menjadi masalah (37 \%). Pemilih pemula masih melihat faktor lain selain jenis kelamin calon.

Tabel 11.

Latar Belakang dan Profesi Calon

\begin{tabular}{|l|c|c|c|}
\hline \multicolumn{1}{|c|}{ Pertanyaan } & \multicolumn{1}{|c|}{ Jawaban } & Jumlah (200) & $\%$ \\
\hline $\begin{array}{l}\text { Latar belakang atau } \\
\text { profesi } \\
\text { calon Bupati yang } \\
\text { sdr/i harapkan. }\end{array}$ & a. Tokoh Pemuda & 46 & $23 \%$ \\
\cline { 2 - 4 } & b. Tokoh Agama & 54 & $27 \%$ \\
\cline { 2 - 4 } & c. Tokoh Masyarakat & 27 & $13,2 \%$ \\
\cline { 2 - 4 } & d. Birokrat & 14 & $7 \%$ \\
\hline & e. Pengusaha & 28 & $14 \%$ \\
\hline & f. Aktivis Partai & 18 & $9 \%$ \\
\cline { 2 - 4 } & g. Lainnya & 13 & $6,5 \%$ \\
\hline
\end{tabular}

Sumber : Data diolah , Agustus 2011

Responden pemilih pemula banyak yang mengharapkan latar belakang calon Bupati Pringsewu mendatang berasal dari tokoh agama (27 \%). Tokoh agama yang di wujudkan dalam tokoh ustad, Kyai atau orang yang ahli dan mengenal agama Islam diasumsikan pemilih pemula sebagai manusia yang mampu menahan nafsu kuasa. Responden menganggap tokoh agama lebih tahan terhadap godaan korupsi,kolusi dan nepotisme dalam menjalankan roda pemerinahan.

Tokoh pemuda (23\%) sebagai representasi dari gairah energik dari kaum muda. Pemuda dianggap sebagai manusia yang aktif dan idealis terhadap segala sesuatu, serta mampu berfikir cepat dan dinamis.

Responden yang memilih pengusaha ( $9 \%$ ) beralasan pengusaha mampu menciptakan lapangan pekerjaan dan mampu secara ekonomi sehingga 
mengurangi perilaku korupsi di jajaran pemerintahan.

Tabel 12.

Usia calon

\begin{tabular}{|l|c|c|c|}
\hline \multicolumn{1}{|c|}{ Pertanyaan } & \multicolumn{1}{|c|}{ Jawaban } & Jumlah (200) & $\%$ \\
\hline $\begin{array}{l}\text { Usia calon Bupati } \\
\text { yang }\end{array}$ & a. Dibawah 30 tahun & 34 & $17 \%$ \\
\cline { 2 - 4 } Sdr/i harapkan & b. $30-40$ tahun & 88 & $44 \%$ \\
\cline { 2 - 4 } & c. $40-50$ tahun & 31 & $15,5 \%$ \\
\cline { 2 - 4 } & d. $50-70$ tahun & 8 & $4 \%$ \\
\cline { 2 - 4 } & e. Usia tidak masalah & 39 & $19,5 \%$ \\
\hline
\end{tabular}

Sumber : Data diolah, Agustus 2011

Usia ideal calon Bupati menganggap bahwa usia $30-40$ mendatang menurut responden tahun adaah usia keemasan dalam hal adalah 30 sampai dengan 40 tahun keaktifan, idealitas, energi fisik dan sebesar $44 \%$. Pola fikir siswa/i SMU sebagai responden penelitian ini pemikiran,

Tabel 13.

Agama Calon

\begin{tabular}{|c|l|c|c|}
\hline \multicolumn{1}{|c|}{ Pertanyaan } & \multicolumn{1}{|c|}{ Jawaban } & Jumlah (200) & $\%$ \\
\hline \multirow{2}{*}{$\begin{array}{l}\text { Agama calon yang } \\
\text { sdr/i harapkan }\end{array}$} & Islam & 150 & $75 \%$ \\
\cline { 2 - 4 } & Kristen, Budha, Hindu dll & 16 & $8 \%$ \\
\cline { 2 - 4 } & Apapun agamanya & 34 & $17 \%$ \\
\hline
\end{tabular}

Sumber : Data diolah, Agustus 2011

Islam merupakan agama yang paling banyak dipilih oleh responden. Calon Bupati mendatang diharakan beragama Islam oleh sebagian besar responden ( $75 \%$ ). Hal ini wajar karena sebagian besar penduduk Kabupaten Pringsewu beragama Islam.

Tabel 14.

Pengalaman calon di bidang pemerintahan (Birokrasi)

\begin{tabular}{|l|l|c|c|}
\hline \multicolumn{1}{|c|}{ Pertanyaan } & Jawaban & Jumlah (200) & $\%$ \\
\hline Apakah calon Bupati & a.Ya, harus & 126 & $63 \%$ \\
\cline { 2 - 4 } Harus berpengalaman di & b. Tidak harus & 41 & $20,5 \%$ \\
\cline { 2 - 4 } Birokrasi & c. Terserah & 33 & $16,5 \%$ \\
\hline
\end{tabular}

Sumber : Data diolah, Agustus 2011

Calon Bupati pringsewu mendatang dinilai oleh para responden, sebesar $63 \%$ menginginkan calon Bupati yang memiliki pengalaman di bidang tata pemerintahan atau birokrasi. Alasnnya adalah untuk mempermudah kinerja Bupati dan lebih mengenal karakter birokrasi dan system kerja mereka. Responden lain sebanyak 20,5\% menganggap pengalaman birokrasi bukan sesuatu yang terpenting, karena Bupati adalah ibarat ketua organisasi yang mengkoordinasikan semua hal. Terpenting adalah Bupati dapat melaksanakan program kerja dan janji politiknya. 
Tabel 15.

Pengusung calon (parpol atau independen)

\begin{tabular}{|l|c|c|c|}
\hline \multicolumn{1}{|c|}{ Pertanyaaan } & \multicolumn{1}{|c|}{ Jawaban } & Jumlah (200) & $\%$ \\
\hline $\begin{array}{l}\text { Mana yang anda sukai, calon } \\
\text { diusung parpol atau } \\
\text { independen }\end{array}$ & a. Parpol & 85 & $42,5 \%$ \\
\cline { 2 - 4 } & b. Independen & 73 & $36,5 \%$ \\
\cline { 2 - 4 } & c. Mana saja & 42 & $21 \%$ \\
\hline
\end{tabular}

Sumber : Data diolah, Agustus 2011

Responden lebih menyukai pasangan calon yang diusung oleh partai politik atau gabungan partai politik dibandingkan pasangan calon independen. Data pada tabel 16 menunjukkan hal tersebut. 42,5\% responden menyukai calon yang berasal dari dukungan partai politik. Responden yang menyukai calon dari jalur perseorangan juga cukup besar sebanyak 36,5 \%.Ini menunjukkan bahwa pemilih pemula sudah memahami bahwa selain partai politik kandidat calon juga dapat menempuh jalur lain selain partai yakni jalur dukungan yang berasal dari masyarakat atau calon perseorangan/independen.

Tabel 16.

Pasangan Calon yang mungkin anda pilih

\begin{tabular}{|l|l|c|c|}
\hline \multicolumn{1}{|c|}{ Pertanyaan } & \multicolumn{1}{|c|}{ Jawaban } & $\begin{array}{c}\text { Jumlah } \\
(200)\end{array}$ & $\%$ \\
\hline Pasangan calon & $\begin{array}{l}\text { a.Ririn Kuswantari \& Subhan } \\
\text { Efendi }\end{array}$ & 42 & $21 \%$ \\
\cline { 2 - 4 } yang mungkin anda & $\begin{array}{l}\text { b.Abd. Fadri Auli \& Tri } \\
\text { Prawoto }\end{array}$ & 22 & $11 \%$ \\
\cline { 2 - 4 } pilih pada Pilkada & $\begin{array}{l}\text { c. Untung Subroto \& } \\
\text { Purwantoro }\end{array}$ & 29 & $14,5 \%$ \\
\cline { 2 - 4 } Pringsewu & $\begin{array}{l}\text { d.Sujadi S. \& Handitya } \\
\text { Narapati }\end{array}$ & 38 & $19 \%$ \\
\cline { 2 - 4 } & $\begin{array}{l}\text { e.Sinung Gatot W \& Mat Alfi } \\
\text { Asha }\end{array}$ & 14 & $7 \%$ \\
\cline { 2 - 4 } & f.Belum menentukan pilihan & 55 & $27,5 \%$ \\
\hline
\end{tabular}

Sumber : Data diolah, Agustus 2011

Tabel 17.

Alasan Memilih Calon

\begin{tabular}{|l|l|l|l|}
\hline \multicolumn{1}{|c|}{ Pertanyaan } & \multicolumn{1}{|c|}{ Jawaban } & Jumlah (200) & \multicolumn{1}{c|}{$\%$} \\
\hline $\begin{array}{l}\text { Alasan sdr/i } \\
\text { memilih calon }\end{array}$ & a. Terkenal (popular) & 51 & $25,5 \%$ \\
\cline { 2 - 4 } pasangan kada & $\begin{array}{l}\text { b. Janji kampanye, } \\
\text { program }\end{array}$ & 30 & $15 \%$ \\
\cline { 2 - 4 } & c. Suka ; Ganteng/ Cantik & 63 & $31,5 \%$ \\
\cline { 2 - 4 } & d. Ikatan keluarga (family) & 22 & $11 \%$ \\
\cline { 2 - 4 } & $\begin{array}{l}\text { e. Kedekatan dengan } \\
\text { public }\end{array}$ & 16 & $8 \%$ \\
\cline { 2 - 4 } & f. Kalangan terdidik/pintar & 11 & $5,5 \%$ \\
\cline { 2 - 4 } & g. Tidak jawab & 7 & $3,5 \%$ \\
\hline
\end{tabular}


Sumber : Data diolah, Agustus 2011

Tabel 18.

Sumber informasi/pertimbangan dalam memilih calon

\begin{tabular}{|l|l|l|l|}
\hline \multicolumn{1}{|c|}{ Pertanyaan } & \multicolumn{1}{|c|}{ Jawaban } & Jumlah (200) & \multicolumn{1}{c|}{$\%$} \\
\hline $\begin{array}{l}\text { Sumber informasi } \\
\text { dan pertimbangan } \\
\text { dalam memilih } \\
\text { pasangan calon }\end{array}$ & a. Orang tua & 45 & $22,5 \%$ \\
\cline { 2 - 4 } & b. Teman atau sahabat & 42 & $21 \%$ \\
\cline { 2 - 4 } & c. Kerabat/ keluarga & 41 & $20,5 \%$ \\
\cline { 2 - 4 } & d. Media (tv, radio, koran) & 28 & $14 \%$ \\
\cline { 2 - 4 } & $\begin{array}{l}\text { e. Spanduk, baliho, } \\
\text { pamflet }\end{array}$ & 38 & $19 \%$ \\
\cline { 2 - 4 } & f. Tidak jawab & 6 & $3 \%$ \\
\hline
\end{tabular}

Sumber : Data diolah, Agustus 2011

\section{Perubahan Pilihan pada saat Pilkada Berlangsung}

Tabel 19.

Apakah pilihan anda masih akan berubah saat pilkada 28 september nanti

\begin{tabular}{|c|l|c|c|}
\hline Pertanyaan & \multicolumn{1}{|c|}{ Jawaban } & Jumlah (100) & $\%$ \\
\hline $\begin{array}{l}\text { Apakah pilihan sdr/i masih } \\
\text { akan berubah saat Pilkada }\end{array}$ & a. ya, sangat mungkin & 126 & $63 \%$ \\
\cline { 2 - 4 } & b. tidak berubah & 74 & $37 \%$ \\
\hline
\end{tabular}

Sumber : Data diolah , Agustus 2011

Tabel 20.

Penyebab perubahan pilihan

\begin{tabular}{|l|l|c|c|}
\hline \multicolumn{1}{|c|}{ Pertanyaan } & \multicolumn{1}{|c|}{ Jawaban } & Jumlah (126) & $\%$ \\
\hline \multirow{3}{*}{$\begin{array}{l}\text { Faktor penyebab pilihan } \\
\text { pada calon berubah }\end{array}$} & a.Popularitas calon lain naik & 18 & $14,3 \%$ \\
\cline { 2 - 4 } & b.Tingkah laku calon & 35 & $27,8 \%$ \\
\cline { 2 - 4 } & c.Janji Kampanye, program & 12 & $9,5 \%$ \\
\cline { 2 - 4 } & $\begin{array}{l}\text { d.Informasi baru, isu politik } \\
\text { (negative campaign) }\end{array}$ & 21 & $16,6 \%$ \\
\cline { 2 - 4 } & e.Pemberian (uang, barang) & 31 & $24,6 \%$ \\
\cline { 2 - 4 } & f.Lainnya & 9 & $7,1 \%$ \\
\hline
\end{tabular}

Sumber : Data diolah, Agustus 2011

\section{Tabel 21.}

Apakah popularitas calon mempengaruhi pilihan anda saat Pilkada berlangsung

\begin{tabular}{|l|l|c|c|}
\hline \multicolumn{1}{|c|}{ Pertanyaan } & Jawaban & Jumlah (200) & $\%$ \\
\hline $\begin{array}{l}\text { Apakah popularitas calon } \\
\text { mempengaruhi pilihan }\end{array}$ & a. Ya, berpengaruh & 108 & $54 \%$ \\
\cline { 2 - 4 } & \begin{tabular}{l} 
b. $\begin{array}{l}\text { Tidak } \\
\text { berpengaruh }\end{array}$ \\
\hline
\end{tabular} & 92 & $46 \%$ \\
\hline
\end{tabular}

Sumber : Data diolah, Agustus 2011 
Tabel 22.

Faktor yang mempengaruhi pilihan politik anda

\begin{tabular}{|l|l|c|c|}
\hline \multicolumn{1}{|c|}{ Pertanyaan } & Jawaban & Jumlah (200) & $\%$ \\
\hline Faktor yang paling & a. Orang tua & 16 & $8 \%$ \\
\cline { 2 - 4 } \begin{tabular}{l} 
berpengaruh dalam \\
menentukan pilihan dalam \\
memilih calon saat Pilkada \\
\cline { 2 - 4 } berlangsung (28 Sept 2011)
\end{tabular} & b. Kakak/ Adik & 10 & $5 \%$ \\
\cline { 2 - 4 } & c. Teman / sahabat & 40 & $20 \%$ \\
\cline { 2 - 4 } & d. Tetangga & 8 & $4 \%$ \\
\cline { 2 - 4 } & e. Diri Sendiri & 46 & $23 \%$ \\
\cline { 2 - 4 } & f. Untung rugi & 28 & $14 \%$ \\
\cline { 2 - 4 } & g. Akal /rasionalitas & 30 & $15 \%$ \\
\cline { 2 - 4 } & h. Intuisi/ perasaan & 18 & $9 \%$ \\
\cline { 2 - 4 } & i. Tidak jawab & 4 & $2 \%$ \\
\hline
\end{tabular}

Sumber : Data diolah , Agustus 2011

\section{Simpulan}

1. Pilkada Pringsewu akan berlangsung dengan tingkat partisipasi yang tinggi, sebesar $92 \%$.

2. Calon Bupati yang diharapkan berasal dari tokoh agama, berusia 41-50 tahun dan beragama Islam. Juga berasal dari putra daerah Pringsewu dan menetap disana. Berjenis kelamin laki-laki.

3. Popularitas calon Bupati, tertinggi dipegang oleh pasangan Ririn K dan pasangan Sujadi.

4. Kaum wanita adalah ladang potensial suara untuk digarap, karena mendominasi 52,8\% dari total responden, dan juga lebih besar dari jumlah pemilih lakilaki berdasarkan DPT Pringsewu 2009 lalu.

5. Partai politik dengan dukungan terbesar adalah Partai Demokrasi Indonesia Perjuangan (PDIP) dengan 28,2 \%, disusul oleh Partai Demokrat dengan 21,3\%, lalu Partai Golkar dengan $13 \%$.

6. $63,5 \%$ pemilih (responden) menyukai calon kandidat yang berasal dari partai politik, sedangkan $36,5 \%$ responden lebih menyukai calon idependen (perseorangan).
7. Ketidaktetapan pilihan publik Pringsewu terlihat pada data bahwa publik lebih menyukai laki-laki sebagai pemimpin (Bupati) dengan $63 \%$. 29,2 \% tidak mempermasalahkan jenis kelamin, dan hanya 7,8 \% yang menyukai wanita menjadi Bupati. Jika dibandingkan dengan popularitas dan elektabilitas, calon wanita berada diatas calon laki-laki dalam survey ini.

\section{Daftar Pustaka}

Budiarjo, Miriam. 1982. Partisipasi dan Partai Politik (Sebuah Bunga Rampai). Yayasan Obor Indonesia. Jakarta 2006. Dasar-

Dasar Ilmu Politik. PT

Gramedia Pustaka Utama. Jakarta

Firmanzah. 2008. Marketing Politik. Yayasan Obor Indonesia. Jakarta

Gaffar, Afan. 1992. Javanese Voters. Gajah Mada University Press. Yogyakarta 1999. Politik Indonesia. Pustaka Jakarta. Jakarta 
Kondrad, Adenaur Stiftung. 2004.

Cara Praktis Mengenal Partai

Politik. PT Raja Grafindo

Persada. Jakarta

Kristiadi, J. 1996. Pemilihan Umum dan Perilaku Pemilih di Indonesia. Prisma. Jakarta

LIP FISIP UI. 2003. Menggugat Partai Politik. LIP FISIP UI. Jakarta

Masyuri dan M. Zainudin. 2008. Metodologi Penelitian (pendekatan praktis dan aplikatif). PT Refika Aditama. Jakarta

Nawawi, Hadari. 1991. Metode Penelitian Bidang Sosial. Gajah Mada University Press. Yogyakarta

Nursal, Adnan. 2004. Political Marketing (Strategi Memenangkan Pemilu). Gramedia. Jakarta

Prajarta Dirdjosanjata dan Nico L Kana (Penyunting). 2006. Demokrasi dan Potret Lokal Pemilu 2004. Pustaka Percik. Yogyakarta

Putra, Fadhilah. 2003. Partai Politik dan Kebijakan Publik. LP3ES. Jakarta

Qadari, Muhammad. 2004. Pergulatan Partai Politik di Indonesia. PT Raja Grafindo. Jakarta

Rudini. 1991. Pelaksanaan Pemilu di Indonesia. Departemen Dalam Negeri. Jakarta

Sastroatmodjo, Sudijono. 1995. Perilaku Politik. IKIP Semarang Press. Semarang

Sudikin dan Mundir. 2005. Metode Penelitian. Insan Cendekia. Surabaya

Surbakti, Ramlan. 1992. Memahami Ilmu Politik. Gramedia. Jakarta 